\title{
Authenticity in marketing: a response to consumer resistance?
}

\author{
Christine Marks \\ Grenoble Ecole de Mangement, \\ 12 Rue Piere Semard, 38000 Grenoble, \\ E-mail: Christine.marks@grenoble-em.com \\ Dr. Melani Prinsloo \\ Grenoble Ecole de Mangement, \\ 12 Rue Piere Semard, 38000 Grenoble, \\ E-mail: Melani.prinsloo@grenoble-em.com
}

Received: 14.06.2015 / Revised: 27.09.2015 / Accepted: 16.10. 2015 / Published online: 30.12.2015

\begin{abstract}
Prior research points out the emerging phenomenon of consumer resistance in terms of resistance towards the marketing discipline. At the same time, extant literature suggests the increasing importance of authenticity in marketing.

This study investigates the research question whether and by which means authenticity in marketing can be a response to consumer resistance. The authors conducted qualitative research within which one part of the interviews was conducted with marketing-resistant participants, another one with non-resistant respondents. This permitted to elaborate on divergences between the two groups concerning the evaluation of authenticity.

The results illustrate that resistant consumers showed a greater sensitivity for authenticity and clear preferences for authentic brands compared to a more indifferent assessment of the comparison group. Resistant consumers were more likely to identify themselves with the presented authentic brands and appreciated their benefits such as autonomy, closeness, quality assurance, individuality and economic rebellion that directly contrast with the elaborated points of criticism about marketing. This suggests that, in order to regain consumers that are critical towards the marketing discipline, the elaborated authenticity facets could be applied to brands as an 'antidote'.
\end{abstract}

JEL classification: M00, M30, M31

Keywords: authenticity, authentic marketing, consumer resistance, marketing skepticism

\section{INTRODUCTION}

The marketing discipline faces an incontrovertible gap between its self-concept and the consumers' perception (Heath and Heath, 2008: 1036). While marketing initially defines its purpose in satisfying customer needs (Kotler et al., 2009: 25), it seems to be facing an image problem nowadays (Sheth and Sisodia, 2006: 26). A form of consumer behavior called consumer 
resistance describes the growing distrust and cynicism toward the entire discipline (Galvagno, 2011; Heath and Heath, 2008; Izberk-Bilgin, 2008; Sheth and Sisodia, 2006) or sub-disciplines such as advertising (Darke and Ritchie, 2007; Rumbo, 2002). Consequential behavior such as ad-avoidance strategies (Rumbo, 2002), boycotting (Fournier, 1998) or brand avoidance (Lee et al., 2009a; 2009b) have been examined in depth but extensive research has not conveyed tangible 'antidotes' to this tendency. The following article contributes to the extant literature by elaborating one possible directive as a way to overcome consumers' resistance towards marketing and regain their trust step by step. The authors examined if and to what extent the phenomenon of authenticity could represent the key to unlock consumer resistance.

Regarding the academic body of work, authenticity (Gundlach and Neville, 2012; Dickinson, 2011; Molleda, 2010; Beverland, 2009; Beverland and Farrelly, 2010; Gilmore and Pine, 2007; Van den Bergh et al., 2009, etc.) as well as consumer resistance (Cherrier, 2009; Fournier, 1998; Heath and Heath, 2008; Holt, 2002; Izberk-Bilgin, 2008; Lee et al., 2009a; 2009b, Obermiller and Spangenberg, 1998,etc.) are increasingly examined in extant research on an exclusive basis. However, previous research has not investigated in depth a possible relationship between the two phenomena. Only slight conjunctions have so far been drawn between the two phenomena (Gustafsson, 2006: 522; Holt, 2002), such as Lee et al. (2009: .423) referring to inauthenticity as one reason for a specific type of brand avoidance or Moore (2003: 104) indicating authentic communication as a valuable means of regaining people's faith in marketing, all of them representing rudimentarily the academic basis for this study.

\section{THE EMERGENCE OF CONSUMER RESISTANCE}

The creation of value for the customer is the ultimate aim of marketing (Armstrong et al., 2009: 3) and could be translated, according to Kotler and Armstrong (2010: 29), into understanding the customer's needs and satisfying them. This definition would imply a comprehensive positive view of the marketing discipline, advocating the customer and improving his life.

However, marketing practices have increasingly been critically questioned and even accused (Galvagno, 2011; Heath and Heath, 2008; Sheth and Sisodia, 2006; Klein, 2002; Rumbo, 2002). The mutually beneficial relationship is perceived to tilt over in such a way that marketing takes an unfair advantage of the consumer and thus becomes unethical (Sheth and Sisodia, 2006: 4). As a consequence, consumer resistance as one form of consumer behavior is theorized (Heath and Heath, 2008: 2025; Izerbg-Bilgin, 2008: 808).

According to Penaloza and Price (1993: 123, following Poster, 1992), the term 'resisting' can be defined as "to withstand the force or effect of" something. Different resistance forms can be classified in terms of their intensity ranging from passive occurrences in terms of avoidance behaviors or downshifting (Lee et al., 2009b: 421), up to active rebellion such as boycotting (Fournier, 1998: 89). This article focuses on resistant consumers who not only incorporate a set of negative attitudes, but also adapt their consumption behavior to their convictions by at least reducing the consumption of specific brands or products. Compared to the concept of anticonsumption, consumer resistance is thus deciphered as a more active form of consumer behavior (Garcia-Bardidia et al., 2011: 1790, Galvagno, 2011: 1699). However, the results can just as well be applied to skeptical or cynic consumers.

Following Holt (2002: 89), the marketplace rejuvenates itself via consumer resistance. But, when not wanting to leave the market to its own devices, it becomes evident that most of the existing studies do not extensively research implications for businesses, intervention strategies or have advice on how to tackle the issue (Cherrier, 2009; Chylinski and Chu, 2010; Heath and Heath, 2008; Izberk- Bilgin, 2008; Obermiller and Spangenberg, 1998). 
In fact, only brief managerial recommendations for upcoming marketing resistance due to branding issues, such as homogenization, saturation and deceptiveness, exist in the extant literature (Dobscha, 1998; Holt, 2002; Lee et al., 2009a).

When anti-clutter advertising does not work anymore (Rumbo 2002: 132), the notions of honesty, genuineness and authenticity are found as "brand avoidance antidotes" (Dobscha, 1998: 96; Lee et al., 2009a: 177). In order to serve the postmodern consumer who creates his identity via brands, "branded cultural resources must be perceived as authentic" (Holt, 2002: 83). Lee et al., (2009a: 177) described the approach against brand avoidance more strategically: "The first antidote involves a genuine adaptation of the brand, one that is initiated from the highest point within the company". This indicates a first hint that authenticity can be a possible solution to consumer resistance.

\section{THE EMERGENCE OF AUTHENTICITY}

The second investigated phenomenon, authenticity, is considered to be a new business imperative (Gilmore and Pine, 2007: 1), being derived from the Latin word 'authenticus' and from the Greek word 'authentikos', meaning "worthy of acceptance, authorative, trustworthy, not imaginary, false or imitation, conforming to an original" (Cappannelli and Cappannelli, 2004: 1).

When classifying authenticity, Grayson and Martinec (2004) distinguished between indexical and iconic authenticity, whereupon the former one is characterized as an object that is "the original" and not an imitation. The index does "refer to cues that (...) are thought to have a factual and spatio-temporal link with something else" (Grayson and Martinec, 2004: 297, following Peirce, 1998). The latter one, iconic authenticity, is depicted as a reproduction or recreation of an indexically authentic object. Following Peirce (1998), an icon is considered as an object that is "perceived as being similar to something" (Grayson and Martinec, 2004: 298).

"Creating authenticity in marketing" is partly considered as a paradox in itself. Once you intend to create it, it seems to become artificial. When authenticity is claimed actively, immediate suspicion may come up (Beverland, 2009: 25). Given the fact that authenticity exists far from mass-markets, provided by unique and artisanal production processes from a place you know (Cova and Cova, 2001: 78), then the term "brand authenticity" can only be considered as a compromise, not reflecting "real authenticity". According to Gilmore and Pine (2007: 89), "All human enterprise is ontologically fake - that is, in its very being it is inauthentic - and yet output from that enterprise can be phenomenologically real - that is, it is perceived as authentic by the individuals who buy it."

The authors took this approach as a basis for the following research, determining as authentic what is considered authentic by consumers, basing it on the construct elaborated above.

\section{THEORETICAL BACKGROUND FOR THE RESEARCH QUESTION}

Based on theoretical secondary research, the authors identified first indications supporting the main research question when regarding the reasons for emergence of both phenomena. Table 1 specifies the key drivers of consumer resistance and authenticity and highlights clear congruencies.

While consumer resistance is a reactive form of consumer behavior (Izberk-Bilgin, 2008: 808; Lee et al., 2009a: 169), authenticity is an active brand proposition (Carroll and Wheaton, 2009: 256; Van den Bergh et al., 2009: 9). The authenticity construct answers the reasons for emergence of authenticity; so for instance does the authenticity facet of uniqueness respond to ubiquity, one reason for emergence of authenticity. As those authenticity drivers are similar to the ones 
for consumer resistance, it seems to be logical that authenticity could also respond to the drivers of consumer resistance. In this case, uniqueness responds equally to saturation, one elaborated reason for the emergence of consumer resistance.

Table 1

Theoretical congruencies of consumer resistance and authenticity

\begin{tabular}{|c|c|c|}
\hline Drivers of consumer resistance & Drivers of authenticity & Responding dimension of authenticity \\
\hline $\begin{array}{l}\text { Corporate domination and cultural } \\
\text { imperialism (Izberk-Bilgin, 2008; } \\
\text { Klein, 2002; Lee et al., 2009a) }\end{array}$ & $\begin{array}{l}\text { Complexities of globalization } \\
\text { (Beverland, 2009: 23) }\end{array}$ & $\begin{array}{l}\text { Heritage and relationship to place } \\
\text { (Beverland, 2006; 2009; Van den Bergh } \\
\text { et al., 2009) }\end{array}$ \\
\hline $\begin{array}{l}\text { Risk perception and functional } \\
\text { dissatisfaction (Kleijnen et al., } \\
\text { 2009; Chylinski and Chu, 2010) }\end{array}$ & $\begin{array}{l}\text { Risk minimization (Lunadro, } \\
\text { 2009; Van den Bergh et al., } \\
\text { 2009) }\end{array}$ & $\begin{array}{l}\text { Quality commitments and method of } \\
\text { production (Beverland, 2006; 2009; } \\
\text { Cova and Cova, 2001) }\end{array}$ \\
\hline $\begin{array}{l}\text { Deceptiveness and loss of trust } \\
\text { (Maathuis et al., 2004; Obermiller } \\
\text { and Spangenberg, 1998) }\end{array}$ & $\begin{array}{l}\text { Loss of institutional trust } \\
\text { (GfK Custom Research, 2010; } \\
\text { Gilmore and Pine, 2007) }\end{array}$ & $\begin{array}{l}\text { Downplaying commercial motives and } \\
\text { quality commitments (Beverland, 2006; } \\
\text { 2009) }\end{array}$ \\
\hline $\begin{array}{l}\text { Homogenization (Brown } \\
\text { and Williams, 2010) }\end{array}$ & $\begin{array}{l}\text { Homogenization } \\
\text { (Lunardo 2009) }\end{array}$ & $\begin{array}{l}\text { Stylistic consistency and sticking to your } \\
\text { roots (Beverland, 2009) }\end{array}$ \\
\hline $\begin{array}{l}\text { Saturation (Gerzema and Lebar, } \\
\text { 2008; Rumbo, 2002) }\end{array}$ & $\begin{array}{l}\text { Ubiquity (Van den Bergh } \\
\text { et al., 2009) }\end{array}$ & $\begin{array}{l}\text { Uniqueness and appearing as artisanal } \\
\text { amateurs (Beverland, 2009; Van den } \\
\text { Bergh et al., 2009) }\end{array}$ \\
\hline
\end{tabular}

\section{RESEARCH METHODOLOGY}

The authors conducted a qualitative study for primary research via semi-structured in-depth interviews, as this is appropriate to explain relationships between two marketing constructs (Shiu et al., 2009: 173). A focus was set on brand management in order to narrow the research field. This seemed adequate as talking about specific brands during the interview helped the interviewees to overcome the difficulty of discussing the abstract authenticity construct. Following Beverland (2009: 27), "one critical manifestation of consumers' search for authenticity is brands". The authors exclusively selected brands of the food sector as all participants were checked to be familiar with the selection of these. Additionally, by sticking to one category, biases due to different category involvement were avoided.

Generally, the sample is a randomly selected convenience sample, typically used in early stages of research (Shiu et al., 2009:480). Heterogeneity in gender, age, profession and education is considered in order to minimize biases (Beverland and Farrelly, 2010: 840).

However, the sample is split along one crucial variable: marketing-resistance. Two groups are interviewed: marketing-resistant people and a group of a similar size with people that are in accordance with or at least accept marketing practices. This adds more depth to the study, allowing for deciphering variances between the groups if they exist. One test interview was executed beforehand in order to validate and test the interview guide in terms of timing and stringency.

For this split, a screening questionnaire identifies each respondent beforehand (see also Appendix 1 for the screening questionnaire). Items are validated statements from the "Handbook of marketing scales" (Bearden et al., 2010).

Table 2 provides an overview of the interviewees and the principal group split. 
Table 2

List of participants and group split

\begin{tabular}{|c|c|c|c|c|c|}
\hline & Respondent & Gender & Age & Education & Profession \\
\hline \multirow{10}{*}{$\begin{array}{r}\text { Group 1: } \\
\text { Non-resistant } \\
\text { participants }\end{array}$} & Ruth & female & 60 & $\begin{array}{l}\text { secondary school ( } 8 \text { years }) \text {, } \\
\text { job training }\end{array}$ & $\begin{array}{l}\text { housewife, } \\
\text { parttime } \\
\text { gardener }\end{array}$ \\
\hline & Stefanie & female & 45 & $\begin{array}{l}\text { secondary school (10 years), } \\
\text { job training }\end{array}$ & bank employee \\
\hline & Ilka & female & 28 & studies of Germanistics & $\begin{array}{l}\text { jobbing } \\
\text { in gastronomy }\end{array}$ \\
\hline & Marie-Bel & female & 25 & $\begin{array}{l}\text { studies of business } \\
\text { administration }\end{array}$ & student \\
\hline & Grid & female & 54 & $\begin{array}{l}\text { studies of history, } \\
\text { Germanistics, theater sciences }\end{array}$ & editor \\
\hline & Sarah & female & 22 & $\begin{array}{l}\text { studies of business } \\
\text { administration }\end{array}$ & student \\
\hline & Tanja & female & 34 & studies of political sciences & PhD student \\
\hline & Christian & male & 25 & $\begin{array}{l}\text { studies of energy and process } \\
\text { engineering }\end{array}$ & student \\
\hline & Jacob & male & 25 & studies of sports and English & student \\
\hline & Respondent & Gender & Age & Education & Profession \\
\hline \multirow{6}{*}{$\begin{array}{r}\text { Group 2: } \\
\text { Resistant } \\
\text { participants }\end{array}$} & Bernd & male & 31 & studies of pedagogy & $\begin{array}{l}\text { circus } \\
\text { pedagogue, } \\
\text { student }\end{array}$ \\
\hline & Anne & female & 27 & $\begin{array}{l}\text { studies of Germanistics, } \\
\text { politics, philosophy }\end{array}$ & $\begin{array}{l}\text { stage direction } \\
\text { assistant }\end{array}$ \\
\hline & Eva & female & 28 & $\begin{array}{l}\text { secondary school (13 years), } \\
\text { fashion designer training }\end{array}$ & self-employed \\
\hline & Malte & male & 25 & studies of physics and English & student \\
\hline & Nils & male & 24 & studies of sports and Spanish & student \\
\hline & Sebastian & male & 26 & studies of nautical sciences & $\begin{array}{l}\text { nautical } \\
\text { inspector }\end{array}$ \\
\hline
\end{tabular}

To summarize, the primary research consisted of two phases:

1) Screening of the participants and classifying them into resistant or non-resistant

2) Conducting the interview.

In order to get a detailed answer to the initial research question "To what extent does authenticity in marketing play a role for people being resistant towards marketing (in comparison to people being in accordance with marketing)?", the researchers elaborated six specific research propositions, breaking down the main research question into six parts. The interview guide was elaborated along these research propositions, with a set of questions in each section aimed at answering specific research propositions. 
The interview consisted of the following subsections (see Appendix 2 for the interview guide):

1) Warm-up

2) Marketing in general and branding

3) Authenticity

4) Influence on buying behavior

After a warm-up at the beginning of the interview, the authors explained the meaning of marketing in order to provide a common knowledge basis for each of the respondents. Interviewees were then asked to elaborate on their attitude towards marketing by means of likes and dislikes and in connection to their consumption behavior. The motivation and reasons for resistance were especially expected to become clear and were assumed to be in line with the elaborated theoretical reasons, that are:

Research proposition P1: Resistant participants criticize marketing due to one or more of the elaborated reasons of domination, cultural imperialism, value incongruence, functional dissatisfaction, perceived risk, deceptiveness, homogenization, saturation.

The third part of the interview elaborated on authenticity and authentic brands. In order to introduce the subject of branding, the authors first asked respondents about their favorite brands and brands they rejected. Subsequently, the authors explained in detail the notion of brand image.

Afterwards, six authentically branded products as well as six inauthentic counterparts were presented to the interviewees at random (classified authentic according to the six authenticity facets of Beverland (2006: 253): Sylter Salatfrische, Tannenzäpfle, Bonne Maman, Fritz Kola, Viva con Agua, Buko and inauthentic: Knorr Salatdressing, Becks, Zentis, Fanta, Vittel, Philadelphia). The authors classified the brands as authentic when they fulfilled the six authenticity dimensions identified by Beverland (2006: 253). Respondents' task then was to split the given brands into two groups according to the most evident differentiation criteria of their brand image. This mapping exercise helped in revealing whether they possessed sensitivity for authenticity or whether they had other differentiation criteria in mind that were consequently relevant to them (Desai, 2002: 121). Hence:

Research proposition P2: Resistant participants are supposed to have a higher sensitivity for authenticity. Thus they are more likely to classify the proposed brands according to authentic and inauthentic brands.

Later on, the authors discussed the term 'authenticity' in detail in terms of its definition and facets. This also happened in reference to the given brands as this facilitated elaborating facets of the construct. Furthermore, this part allowed figuring out whether there were differences in perceptions of authenticity between the groups. As "detailed knowledge may be required to identify authentic varieties" (Carroll and Wheaton, 2009: 260) and knowledge about specific cues attributing authenticity are necessary (Beverland, 2009: 25), it can be concluded that:

Research proposition P3: Resistant participants have a clearer understanding about the notion of authenticity.

After having specified the authenticity concept, an evaluation took place in the last part in order to elaborate the consumers' motivations within the quest for authenticity. Following the results of Lee et al. (2009b: 423), inauthenticity is one reason for brand avoidance. Vice versa, authenticity could be an important attribute for (re-)engaging with brands. This is supported by Moore's work (2003: 522) that points out the importance of authentic communication for people who have lost faith in marketing. That is:

Research proposition P4: Resistant participants obtain more important benefits of the consumption of authentically branded products compared to non-resistant participants.

Research proposition P5: Authentic brands could help (re-)gain resistant participants' enthusiasm for marketing.

In this part, the respondents elaborated on the influence authenticity can have on them and were asked directly about the authenticity paradox in order to check on credibility and business 
implications. It was assumed that non-resistant participants were not bothered in depth about the subject and consequently neither about the paradox, given the fact that the authenticity paradox takes place at a meta-level and implies being engaged with the subject (Beverland, 2009: 25).

Research proposition P6: Resistant participants are more concerned with the paradox of "created authenticity" from marketing.

\section{RESEARCH FINDINGS}

\subsection{Attitudes about marketing}

\section{Understanding of marketing}

When analyzing the results of the word association test for marketing, clear differences in the initial associations between the two differing groups could be ascertained. The non-resistant interviewees mostly employed a descriptive approach, associating it with advertising such as TV commercials. Furthermore, the activity of marketing itself was tried to be explained as "selling products" or "creating awareness". Sporadically, appreciative evaluations or tangible associations as "Apple, black sunglasses" occurred.

In contrast to this, the group of resistant respondents instantly came up with various negative judgments and evaluations. The participants stated their rejection from several perspectives, on the one hand describing marketing's techniques as being "manipulative, kidding people and controlling one's behavior", and on the other hand criticizing a broader capitalistic scope, mentioning "huge volumes" and mechanisms such as "outmatching others". The definition of marketing was clearly less objective, e.g. "convince for buying" instead of "bringing products to the market" in the non-resistant group. Once again, resistant interviewees added judgments even when mentioning advertising (described directly in a negative way as dull or crappy).

\section{Marketing evaluation}

Evident differences also manifested between the two groups when it came to stating positive and negative aspects of marketing. Non-resistant participants indicated more important personal benefits of the marketing discipline for themselves, such as variety and diversity, information and orientation as well as entertainment. Their criticism points can be circled down to deceptiveness, saturation and monotony.

Regarding the resistant participants' positive mentions, their focus lay on quality improvements and the initial development of products.

Concerning the negative aspects of marketing, the number of mentions relative to the number of participants of this group increased, as well as the intensity of the main points of criticism that could be deducted from the mentions:

- Manipulation: Similarly to the previous group results, the issue of dishonesty in marketing dominated. But in contrast to the non-resistant group, where deceptiveness was the main issue, in this group the gravity of criticism increased. Respondents complained about a purposeful attempt of influencing and controlling the consumer's behavior, thus it was seen at a more personal level.

- Lack of quality: A lack of product quality was another major aspect that was elaborated on, referring to predominant superficiality and exclusive profit-orientation of corporations instead of high quality, functionality and customer service. This was a major issue for three of the respondents, also because quality was one of the main purchasing criteria. 
- Abundance: Huge quantities of advertising and marketing activities were also criticized, supporting extant literature suggesting information overload as an "important antecedent to resistance" (Kleijnen et al., 2009: 350). Respondents mentioned the permanent exposure to advertising but also the financial resources that are wasted. Additionally, saturation and subsequently irrelevant product innovations go along with this.

- Disturbing and aggressive advertising was another aspect, aimed at selling as much as possible. Exaggerations such as "mega, hyper, super" in advertising were disliked and might result in consumer skepticism (Obermiller and Spangenberg, 1998: 159).

In conclusion, research proposition P1 can be supported; respondents criticize marketing due to the theoretically elaborated reasons of value incongruence, functional dissatisfaction, deceptiveness, homogenization and saturation. For the group of resistant participants, the aspect of domination could be added, as well as a greater depth of criticism in terms of purposeful manipulation.

\section{Attitude towards brands}

The results of discourses about brands suggest a different enthusiasm about these. While the resistant group preferred brands such as Miele, Manufactum, NoaNoa due to quality attributes, participants of the non-resistant group also indicated that they were inspired by sophisticated brand images (Adidas, Lacoste, Massimo Dutti) and could feel enthusiastic about superficial attributes such as the packaging color. In terms of brand rejection, the results of resistant respondents clearly conveyed two main reasons for disapproval:

- Value incongruence of the individual and the company behind a brand was the most important reason among resistant participants when it comes to rejecting specific brands, supporting the findings of Chylinski and Chu (2010: 800). More specifically, this concerns bad working conditions and unfair treatment of the employees for which brands such as Nike or Lidl are rejected. Secondly, the disapproval of an organization's political attitude reinforces rejection of a brand.

- Corporate domination is one of the triggers exclusively mentioned by the resistant group. Huge organizations are consequently rejected due to their power and size, such as McDonalds or Coca Cola (supporting the argumentation of Lee et al., 2009b: 423). Inconsistencies in the corporate image and an unfair pricing policy are further motives for rejecting brands.

\subsection{Sensitivity for authenticity}

In order to elicit the sensitivity for authenticity, participants were asked to classify the brands that had been presented to them at random. The split was to be pursued according to differences in brand image in two groups. The term authenticity had not been mentioned beforehand. Following research proposition $\mathrm{P} 2$, critical respondents would rather be able to divide products according to the "authenticity split" conceived according to the authenticity dimensions by Beverland (2006: 253) compared to non-critical respondents.

The qualitative data suggests that all participants of the resistant group classified the products according to the assumed way. Their differentiation criterion was always either the size, degree of common knowledge or power of the brands. Inauthentic brands were named "mainstream, dominating, mass-market, commercial, powerful" whereas the authentic brands were called "underdog, no-name, personal, good world, less known". This indicates that critical respondents had as a first thought the intended split in mind and attributed facets of authenticity to the brands as a classification criterion. 
Contrarily, in the group of non-resistant participants, not even half of the participants divided the products in the intended way, also classifying them according to the degree of knowledge, mass-market or conventionality. Consequently, five out of nine interviewees built up a different split, choosing different differentiation criteria, such as "health-indulgence, dynamic-traditional, civic-fresh, everyday-lifestyle, associations-no image”.

This is a first indication and supports research proposition P2 that resistant consumers tend to have a greater sensitivity for authenticity and for authentic brands. Another fact supporting this assumption is that two respondents of the resistant group came up by themselves with the notion of authenticity and sanguinity without needing to be prompted. The fact that the rest of participants in this group did not come up with the word authenticity itself but described facets of it, such as "closeness, good-world, niche-character, no profit-orientation" suggests that the concept is perceived unconsciously.

Regarding the rest of the respondents who were prompted and asked which group (or, if a 'wrong' split was made, which brands) are more authentic, all resistant respondents attributed authenticity to the authentic brands and declared to prefer this group of brands. In contrast, only two out of nine non-resistant participants attributed authenticity to authentic brands. These findings also support the proposition that resistant respondents have a greater sensitivity for authenticity. In consequence, research proposition P2 is substantiated.

\subsection{Definition and facets of authenticity}

In coherence with what extant literature suggests (Cappannelli and Cappannelli, 2004: 1; Davis, 2010: 139; Molleda, 2009: 87; Taylor, 2001: 8), the research findings reveal various definitions of the term authenticity. However, no evident differences between the groups occurred in this part. Consequently, research proposition P3 cannot be confirmed. Mostly, informants defined authenticity as honesty, truthfulness and genuineness. Furthermore, characterizations of consistency, integrity and credibility were predominantly mentioned.

As the brands that were used in the interviews had been chosen according to the theoretical elaborated attributes of authenticity based on Beverland (2006: 253), similarities with the facets resulting from this study are a logical consequence. The authors identified the following major facets of authenticity from the interviews:

- Low commercialization is one main elaborated aspect as this conveys the contrasting position to global companies and supports small companies and the niche character of organizations. Confirming Beverland's (2006: 256) authenticity facet of downplaying commercial motives, respondents in this study also mentioned the attribute of having other objectives than profit-orientation.

- Nostalgia as a facet is mainly revealed via executional details such as the typical ancient milk bottle form of Sylter Salatfrische, the traditional reference via the date on the packaging (1791 for Rothaus) and the handmade appeal transferred by Bonne Maman.

- Exclusiveness is closely connected to the previous facet, by means of conscious production and a small production lot size which indicate rarity of the product.

- Consistency is another important facet of authentic brands that has been revealed by the research results. Differing from Beverland's findings (2006: 253), this does not only include constancy and few changes in design but is also attributed to the consistency of the information communicated to the outside versus the actual ingredients, thus referring to honesty. It also includes the consistency of the communicated brand image and the actual product. Vice versa, brands as Coca Cola claiming health and sponsoring sports are considered to be inauthentic. 
- Disinterestedness could also be described as inner-orientation, representing the opposite of the typical market-orientation. Thus, participants mentioned individualism, being true to oneself and not exclusively focusing on the consumers' needs. Consequently, an authentic brand is not staging itself and pushing itself in the foreground. This supports Goldstein's point of view:

"The brand reeks of authenticity. The fact that it's not advertised everywhere and whispers rather than shouts its benefits, helps [it] convey something meaningful and subtle to consumers" (Goldstein, 2003: 62, following Beverland et al., 2008).

- Simplicity is another facet revealed by the research results, being closely connected to the previous notion of disinterestedness. It refers mainly to the executional aspect of a plain and simple design, contrasting classical brands' stylish make-ups.

- Regionality in terms of local-rootedness is another aspect, representing an important basis for the benefits authenticity delivers such as identification described within this study. This context around an authentic brand is described as referential authenticity (Gilmore and Pine, 2007: 49).

- Personalization similarly provides a basis for identification for the participants due to e.g. the two faces on the Fritz Kola logo that convey humanity and assurance of good quality.

- Transparency is the last facet of authentic brands revealed by the research results, referring to the communication of the product's make-up. It should be as clear as possible, implemented via visible information on the packaging or via disclosure of the method of production, supporting Beverland's findings (2006: 255).

\subsection{Benefits of authenticity in consumption}

When asking respondents about the importance of authentic brands or to what extent authenticity plays a role for the interviewees, findings suggest that proposition $\mathrm{P} 4$ can be supported: all resistant participants indicated their preference for authentic brands and re-explained why authenticity was important to them. This supports Woodruffle-Burton and Wakenshaw (2011: 70) who pointed out the construction of identity and the self via consumption. Their elaboration on benefits of the consumption of authentically branded products was much more detailed and deciphered to what extent they value authenticity. In contrast, only one out of nine non-critical participants clearly stated the importance of authenticity, whereas the rest of this group clearly was less involved. Accordingly, those people indicated benefits they got from the consumption of inauthentic brands.

Concerning authentic brands, the qualitative data permits conveying six main benefits that are provided by these. The authors based the results on indications of all participants. This is because there were few differences between the groups in terms of the kind of mentions of benefits but in the evaluation of importance of these benefits.

- Quality assurance is the sole functional benefit delivered by authentic brands within this study. It is provided by truthfulness and assumed conscious production as well as by executional details, as for instance the two faces of Fritz Kola that are "assuring with their face that the product has a certain quality".

- Autonomy is highlighted as a principal benefit by the research findings. This supports one of the main benefits Beverland and Farrelly (2010) pointed out in their research under the aspect of 'control', referring to "personal sovereignty over consumption choices" (Beverland and Farrelly, 2010: 842). Respondents of this study depicted this as making conscious purchasing decisions, being critical in their product choice and due to the disinterestedness of authentic brands respondents felt rather free from marketing influence in their choices. 
- Closeness refers on the one hand to a notion of warmth, either expressed by the personal appeal, by the emotions of nostalgia or by down-to-earthiness of the brands that are transmitted for instance by the founder myth. On the other hand, regional connectedness transmits closeness. Knowing about a brand's origin permits the participants to develop a trust relationship with the brand, which is crucial as trust is closely linked to authenticity (Gustafsson, 2006: 522). When coming from the same city, respondents partly even pointed out a "feeling of belonging with the product".

- Individuality allows participants to distinguish themselves from the mainstream and to claim distinctiveness and exclusiveness, being partly also connected to the rarity of the products.

- Economic rebellion is experienced by the participants from two directions. Supporting small "underdog brands" is one idea participants want to express in order to foster alternative ideas and diversity, whereas rebellion against the big global brands depicts the reverse side. This occurred mainly with resistant respondents in a very predominant and conscious way, with notions of wanting to 'hurt' the big players.

- Identification is one main emotional benefit of authentic brands emerging from this study. Several respondents mentioned value congruence between the brand's and their own values (e.g. truthfulness or social responsibility). One participant underlined this point: "I can identify with these products, it is consistent with my convictions". This quotation is a salient example of how participants share values and beliefs with those brands. Additionally, when consuming authentic products in public, they also have a self-expressive function as to communicating a certain mindset and convictions. Literature suggests that an expressive and self-identification function helps consumers to communicate certain messages about themselves such as their values or what they find valuable to aspire for (Franzen and Moriarty, 2008: 85).

\section{CONCLUSION}

The initial question of this research has been to find out to what extent authenticity in marketing plays a role for people being resistant towards marketing, compared to people being in accordance with marketing.

The research pointed out the main points of criticism about marketing for both non-resistant and resistant participants. The latter ones confirmed deeper and more intense disadvantages of the discipline and felt personally more involved in the subject.

Analyzing the results in a broader context, the assumption comes up that an overall political criticism correlates with consumer resistance. This is suggested by the findings as the resistant participants tended to criticize the capitalistic system as a whole, including the large, dominating organizations it supports, but not only marketing specifically.

In the course of the study, it was illustrated that resistant respondents showed a greater sensitivity for authentic brands and had more ease in classifying the proposed products according to an authentic and inauthentic brand image. However, their understanding of the notion of authenticity was not explicitly clearer (although they were more at ease talking about brand image).

Nevertheless, resistant respondents had clearer preferences for authentic brands compared to inauthentic brands and indicated valuable benefits of authenticity for them, whereas non-resistant respondents also showed preferences for "mainstream brands" and pointed out several benefits of them. When asking them directly, all resistant respondents admitted that authentic brands could help (re-)gain enthusiasm for marketing. Consequently, the crucial research proposition P5 can be supported. 
Figure 1 summarizes the elaborated findings of this study and provides an answer to the main research question, as it deciphers which benefits of authenticity provide a direct response to the points of criticism that are those of the resistant group of interviewees.

Figure 1

Facets of authenticity accounting for benefits that oppose marketing criticism points

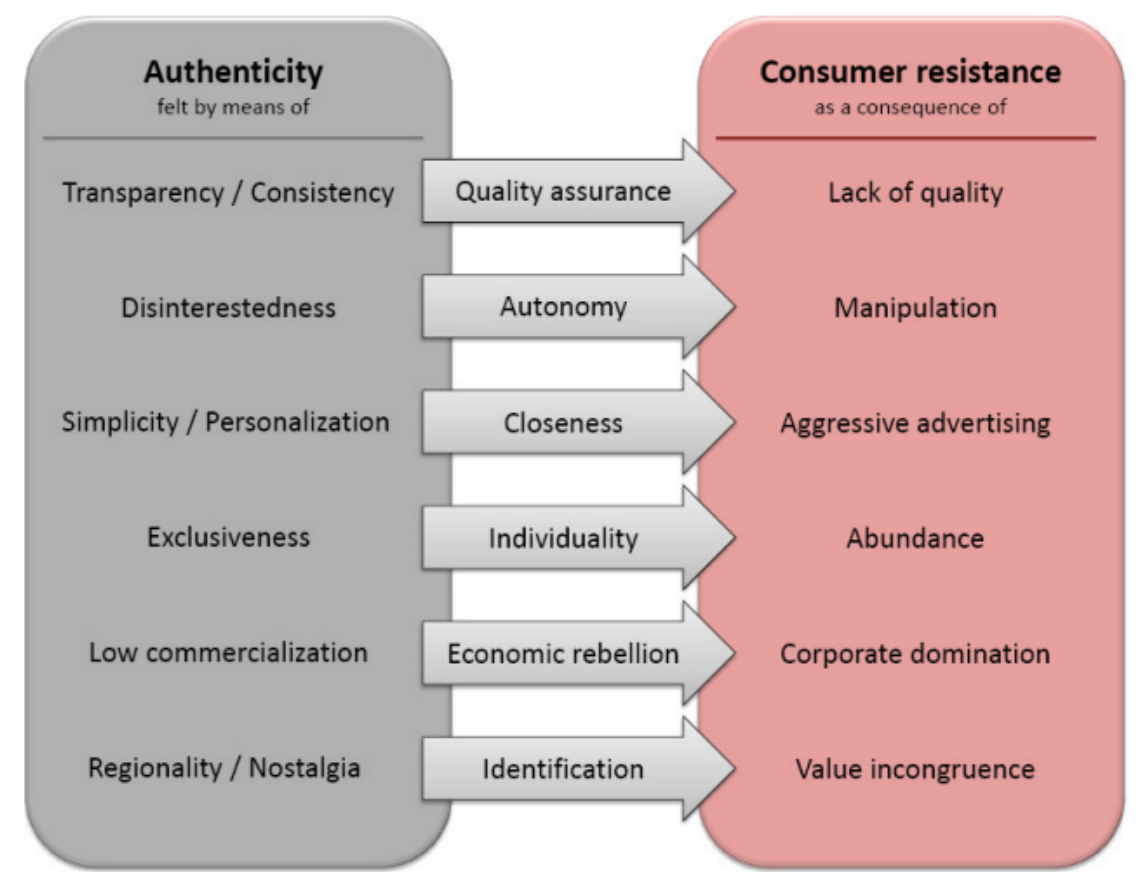

On the left side the facets of authenticity are listed. One or two of them account mainly (but not exclusively) for one benefit delivered by authentic brands. These are illustrated by the arrows and each directly contrasts with one point of criticism mentioned for marketing. These criticism points on the right side are the ones mentioned by the resistant group, elaborated in this study within the section of marketing evaluation and reasons for rejecting brands.

For instance, the facets of consistency and transparency provide assurance of quality to the consumer and oppose the criticism of lacking quality which turned out to be one main criticism point resistant consumers claimed. The inner-orientation or disinterestedness facet of authenticity provides the consumer with autonomy and freedom of choice as he is not purposefully manipulated and influenced in his buying decision. Another stated criticism point of marketing was aggressive advertising that provokes a distance and annoyance with the consumer. This upcoming distance can be opposed by authenticity facets in terms of personalization or simplicity as they transmit the emotional benefit of closeness. The criticism of overload and abundance can be contrasted by individuality, provided by the authentic brand facet of exclusiveness and rarity. Closely connected is the notion of low commercialization that often refers to a small company size and provides consumers with a feeling of rebellion against the big players, consequently opposing corporate domination structures. Finally, regional or nostalgic attributes of brands help to create identification with an authentic brand that is the opposite of value incongruence.

This conclusive image shows vividly that authenticity with all its facets can obviously be considered as an antidote for consumer resistance, especially as the criticism points are the ones mentioned by resistant respondents.

Moreover, this graph serves not only as an overview of the research results, but at the same time contains managerial implications. That is, if a brand aims to address resistant consumers or 
aims to shift its negative brand image at a specific point of criticism, the corresponding antidote could be reinforced in communication.

However, it has to be considered that this is a rough overview, whereas authenticity is a holistic concept in itself of which several facets contribute to several benefits (e.g. regionality was indicated to also convey closeness). This is not explicitly shown here due to the simplification of the graphic.

Furthermore, business implications need to be considered prudently because providing "perceived authenticity" goes hand in hand with a credibility issue and can quickly evoke a paradox. Nevertheless, this graphic highlights the power of authenticity when the question is about coping with the phenomenon of consumer resistance; with honesty and truthfulness, one is assured to be on the right track.

\section{RESEARCH LIMITATIONS}

The most important limitation within this study is the small sample size. This allows no generalizations as it lacks reliability (Shiu et al., 2009: 174) and consequently the findings need to be considered within the context and frame in which the study was conducted. The quantity of the sample is not representative and coincidental specifics that might result do not at all represent a global view. In addition, there was no split according to age, gender, education or other sociodemographic variables due to the convenience sample. Thus, involuntary biases could be the consequence.

Furthermore, the content and validity of the screening questionnaire and the classification of participants according to resistant and non-resistant respondents are not objective matters, and both the questionnaire and the classification could have been conducted differently. The order of the questions as well as the different degrees of confidence toward the interviewees can also have an influence on the answers.

Moreover, the reduction of the chosen brands to one category, fast moving consumer goods, might reveal results that are not necessarily a representative account for other categories and consequently no generalization is possible (as talking about authenticity in general). The elaborated criticisms predominantly refer to consumer markets and reveal nothing about the perception of B2B or non-profit marketing. Furthermore, interviewees were only asked about the proposed brands, thus their enthusiasm about authentic brands does not automatically imply an enthusiasm about authenticity in marketing in general.

Within the analysis, inaccuracies due to translation may occur. Later on, the analysis is a subjective matter and could have been done differently by another person. "Though the analysis is based on the descriptions presented by the interviewees, the interpretations in the final report are those of the researcher" (Rubin and Rubin, 2005: 201). In any case, the analysis is speculative as it is a theoretical interpretation and consequently no proof of any kind but rather represents conjectures.

\section{FUTURE RESEARCH}

First of all, further research is needed in order to verify the validity of the research results. A quantitative study could be appropriate for quantifying the ability of authenticity to gain or regain marketing enthusiasm among resistant consumers. This could also be useful for categorizing people more specifically according to their demographics and to see whether and how socio-demographic variables influence consumer resistance and the appeal of authenticity. More concretely, a relationship between an overall political criticism and the effects on consumer 
behavior and a critical attitude is suggested by the results of this study and could be investigated quantitatively. The same would be interesting for a correlation between the preference for organic food and for authentic brands as well as the correlation between intelligence and consumer resistance, as both relationships were assumed in this study.

Supplementary validation would also be provided by researching professional opinions such as those of marketing managers or brand managers on the subject. This would also be of managerial use in order to work out more specifically the application of authenticity in branding.

Furthermore, as this study is only focused on fast moving consumer goods, further research concerning authenticity in other domains such as high-involvement products or services might be of interest. This extension would also make sense for the other levels such as organizational authenticity or authenticity in advertising.

\section{Reference list}

Armstrong, G., Harker, M., Kotler, P. and Brennan, R. (2009), Marketing: An Introduction, USA, Pearson Education. Bearden, W.O., Haws, K.L. and Netemeyer, R.G. (2010), Handbook of Marketing Scales: Multi-Item Measures for Marketing and Consumer Behavior Research, UK, SAGE Publications.

Beverland, M.B. (2006), The 'real thing': Branding authenticity in the luxury wine trade, Journal of Business Research, vol. 59(2), 251-258.

Beverland, M.B., Lindgreen, A. and Vink, M.W. (2008), Projecting Authenticity through Advertising - Consumer Judgments of Advertisers' Claims, Journal of Advertising, vol. 37(1), 5-15.

Beverland, M.B. (2009), Building Brand Authenticity - 7 Habits of Iconic Brands, UK, Palgrave Macmillan.

Beverland, M.B. and Farrelly, F.J. (2010), The Quest for Authenticity in Consumption: Consumers' Purposive Choice of Authentic Cues to Shape Experienced Outcomes, Journal of Consumer Research, vol. 36(5), 838- 856.

Brown, S., Kozinets, R.V. and Sherry Jr., J.F. (2003), Teaching Old Brands New Tricks: Retro Branding and the Revival of Brand Meaning, Journal of Marketing, vol. 67(3), 19-33.

Brown, D. and Williams, D. (2010), Do copycat brands reflect a lack of creativity in marketing?, Marketing, vol. 8(22).

Cappannelli, G. and Cappannelli, S. (2004), Authenticity: Simple Strategies for Greater Meaning and Purpose at Work and at Home, USA, Emmis Books.

Carroll, G.R. and Wheaton, D.R. (2009), The organizational construction of authenticity: An examination of contemporary food and dining in the U.S., Research in Organizational Behavior, vol. 29, 255-282.

Cherrier, H. (2009), Anti-consumption discourses and consumer-resistant identities, Journal of Business Research, vol. 62(2), 181-190.

Chylinski, M. and Chu, A. (2010), Consumer cynicism: antecedents and consequences, European Journal of Marketing, vol. 44(6), 796-837.

Cova, B. and Louyot-Gallicher, M. (2006), Innover en marketing: 15 tendances en mouvement, France, Tec \& Doc Lavoisier.

Cova, V. and Cova, B. (2001), Alternatives marketing: réponses marketing aux évolutions récentes des consommateurs, France, Dunod.

Darke, P.R., Ashworth, L. and Main K.L. (2010), Great expectations and broken promises: misleading claims, product failures, expectancy disconfirmations and consumer distrust, Journal of the Academy of Marketing Science, vol. 38(3), 347-362.

Darke, P.R. and Ritchie, R.J.B. (2004), One Rotten Apple Spoils the Barrel: Advertising Deception, Defensive Processing, and Consumer Suspicion, in Darke, P.R., Consumer Reactions to Marketing Practices: Skepticism, Suspicion and Payback, Advances in Consumer Research, vol. 31(1), 329-332.

Darke, P.R. and Ritchie, R.J.B. (2007), The Defensive Consumer: Advertising Deception, Defensive Processing, and Distrust, Journal of Marketing Research, vol. 44(1), 114-127.

Davis, J.A. (2010), Competitive Success - How branding adds value, UK, John Wiley \& Sons.

Desai, P. (2002), Methods beyond interviewing in qualitative market research, UK, SAGE.

Dickinson, J.B. (2011), The role of authenticity in relationship marketing, Journal of Management and Marketing Research, vol. 8, 1-12.

Dobscha, S. (1998), The Lived Experience of Consumer Rebellion Against Marketing, Advances in Consumer Research, vol. 25(1), 91-97.

Ekici, A. (2007), Distrust: An Alternative Source of Power for Consumers, Advances in Consumer Research, vol. 34, 438-439. 
Forehand, M.R. and Grier, S. (2003), When Is Honesty the Best Policy? The Effect of Stated Company Intent on Consumer Skepticism, Journal of Consumer Psychology, vol. 13(3), 349-356.

Fournier, S. (1998), Consumer Resistance: Societal Motivations, Consumer Manifestations, and Implications in the Marketing Domain, Advances in Consumer Research, vol. 25(1), 88-90.

Franzen, G. and Moriarty, S. (2008), The Science and Art of Branding, USA, M.E. Sharpe.

Galvagno, M. (2011), The intellectual structure of the anti-consumption and consumer resistance field, European Journal of Marketing, vol. 45(11/12), 1688-1701.

Garcia-Bardidia, R., Nau, J., Rémy, E. (2011), Consumer resistance and anti-consumption, European Journal of Marketing, vol. 45(11/12), 1789-1798.

Gerzema, J. and Lebar, E. (2008), The brand bubble - The looming crisis in brand value and how to avoid it, USA, Jossey-Bass.

Gilmore, J.H. and Pine II, B.J. (2007), Authenticity - What Consumers really want, USA, Harvard Business School Press.

Goldstein, N. (2003), What's Up Doc? Australian Financial Review Magazine, (Summer), 62.

Grayson, K and Martinec, R. (2004), Consumer Perceptions of Iconicity and Indexicality and their Influence on Assessments of Authentic Market Offerings, Journal of Consumer Research, vol. 31(2), 296-312.

Gundlach, H. and Neville, B. (2012), Authenticity: Further theoretical and practical development, Journal of Brand Management, vol. 19(6), 484-499.

Gustafsson, C. (2006), Brand Trust and Authenticity: The Link between Trust in Brands and the Consumer's Role on the Market, European Advances in Consumer Research, vol. 7, 522-527.

Heath, M.T.P. and Heath, M. (2008), (Mis)trust in marketing: A reflection on consumers' attitudes and perceptions, Journal of Marketing Management, vol. 24(9/10), 1025-1039.

Holt, D.B. (2002), Why Do Brands Cause Trouble? A Dialectical Theory of Consumer Culture and Branding, Journal of Consumer Research, vol. 29(1), 70-90.

Izberk- Bilgin, E. (2008), When Starbucks Meets Turkish Coffee: Cultural Imperialism and Islamism as 'Other' Discourses of Consumer Resistance, Advances in Consumer Research, vol. 35, 808-809.

Kanter, D.L. and Wortzel, L.H. (1985), Cynicism and alienation as marketing considerations: Some new ways to approach the female consumer, Journal of Consumer Marketing, vol. 2(1), 5-15.

Kleijnen, M., Lee, N. and Wetzels, M. (2009), An exploitation of consumer resistance to innovation and its antecedents, Journal of Economic Psychology, vol. 30(3), 344-357.

Klein, N. (2002), No Logo! No Space. No Choice. No Jobs, UK, Harper Collins Publishing.

Kotler, P., Keller, K.L., Brady, M., Goodman, M. and Hansen, T. (2009), Marketing management, UK, Pearson Education.

Kotler, P. and Armstrong, G. (2010), Principles of Marketing, USA, Pearson Education.

Lee, K. (2008), Opportunities for green marketing: young consumers, Marketing Intelligence \& Planning, vol. 26(6), 573-586.

Lee, M.S.W., Motion, J. and Conroy, D. (2009a), Anti-consumption and brand avoidance, Journal of Business Research, vol. 62(2), 169-180.

Lee, M.S.W., Motion, J. and Conroy, D. (2009b), Brand Avoidance: A Negative Promises Perspective, Advances in Consumer Research, vol. 36, 412-429.

Lunardo, R. (2009), The influence of label on wine consumption in Canavari, Maurizio, Cantore, Nicola, International marketing and trade of quality food products, Netherlands, Wageningen Academic Publishers, 280-295.

Maathuis, O., Rodenburg, J. and Sikkel, D. (2004), Credibility, Emotion or Reason?, Corporate Reputation Review, vol. 6(4), 333-345.

Molleda, J. (2009), Construct and Dimensions of Authenticity in Strategic Communication Research, Anagramas, vol. 8(15), 85-97.

Molleda, J. (2010), Authenticity and the construct's dimensions in public relations and communication research, Journal of communication management, vol. 14(3), 223-236.

Moore, J. (2003), Authenticity, in Ind, N., Beyond branding, UK, Kogan Page, 104-121.

O'Shaughnessy, J. and O'Shaughnessy, N.J. (2002), Marketing in the Consumer society and Hedonism, European Journal of Marketing, vol. 36 (5/6), 524-547.

Obermiller, C. and Spangenberg, E.R. (1998), Development of a Scale to Measure Consumer Skepticism Toward Advertising, Journal of Consumer Psychology, vol. 7(2), 159-186.

Peirce, C.S. (1998), Collected Papers of Charles Sanders Peirce, editors: Hartshorne, C. and Weiss, P., 8 vols, UK, Thoemmes.

Penaloza, L., and Price, L.L. (1993), Consumer Resistance: A Conceptual Overview, Advances in Consumer Research, vol. 20, 123-128.

Pollay, R.W. and Mittal, B. (1993), Here's the Beef: Factors, Determinants, and Segments in Consumer Criticism of Advertising, Journal of Marketing, vol. 57(3), 99-114. 
Porter, M.E. (1998), Competitive advantage: creating and sustaining superior performance: with a new introduction, USA, The Free Press, Simon and Schuster.

Poster, M. (1992), The Question of Agency: Michel de Certeau and the History of Consumerism, Diacritics, vol. 22(2), 94-107.

Roux, D. (2007), Consumer Resistance: Proposal for an integrative framework, Recherche et Applications en Marketing, vol. 22(4), 59-79.

Rubin, H.J., and Rubin, I. (2005), Qualitative interviewing: The art of hearing data, UK, SAGE Publications.

Rumbo, J.D. (2002), Consumer Resistance in a World of Advertising Clutter: The Case of Adbusters, Psychology \& Marketing, vol. 19(2), 127-145.

Schmidt, M.J. and Hollensen, S. (2006), Marketing Research: An International Approach, UK, Pearson Education.

Sheth, J.N. and Sisodia, R.S. (2006), Does Marketing Need Reform? - Fresh Perspectives on the Future, USA, M.E. Sharpe Inc.

Taylor, J.P. (2001), Authenticity and sincerity in tourism, Annals of Tourism Research, vol. 28(1), 7-26.

Van den Bergh, J., De Ruyck, T. and Van Kemseke, D. (2009), Even better than the real thing - understanding generation Y's definition of 'authenticity' for the Levi's brand, ESOMAR World Research Conference, 8-19.

Woodruffle-Burton, H. and Wakenshaw, S. (2011), Revisiting experiential values of shopping: consumers' self and identity, Marketing Intelligence \& Planning, vol. 29(1), 69-85.

\section{APPENDIX}

\section{Screening questionnaire}

Respondent No.

\begin{tabular}{|c|c|c|c|c|c|c|}
\hline Items & $\begin{array}{l}1 \\
\text { Strongly } \\
\text { agree }\end{array}$ & $\begin{array}{l}2 \\
\text { Agree }\end{array}$ & $\begin{array}{l}3 \\
\text { Rather } \\
\text { agree }\end{array}$ & $\begin{array}{c}4 \\
\text { Rather } \\
\text { disagree }\end{array}$ & $\begin{array}{l}5 \\
\text { Disagree }\end{array}$ & $\begin{array}{c}\quad 6 \\
\text { Strongly } \\
\text { disagree }\end{array}$ \\
\hline \multicolumn{7}{|l|}{$\begin{array}{l}\text { 1. "What is seen on the outside of a package is many } \\
\text { times not what you get on the inside." (Lundstrom and } \\
\text { Lamont, 1976) }\end{array}$} \\
\hline \multicolumn{7}{|l|}{$\begin{array}{l}\text { 2. "When a product is advestised as 'new' or 'improved' } \\
\text { it is the same old thing only in a different package." } \\
\text { (Lundstrom and Lamont, 1976) }\end{array}$} \\
\hline \multicolumn{7}{|l|}{$\begin{array}{l}\text { 3. "I believe advertising is informative." (Obermiller } \\
\text { and Spangenberg) }\end{array}$} \\
\hline \multicolumn{7}{|l|}{$\begin{array}{l}\text { 4. "Quite often adverstising is amusing and entertaining." } \\
\text { (Pollay and Mittal, 1993) }\end{array}$} \\
\hline \multicolumn{7}{|l|}{$\begin{array}{l}5 \text { "We can depend on getting the truth in most } \\
\text { advertising." (Obermiller and Spangenberg, 1998) }\end{array}$} \\
\hline \multicolumn{7}{|l|}{$\begin{array}{l}\text { 6. "Most advertising is very annoying." (Gaski and Etzel, } \\
\text { 1986) }\end{array}$} \\
\hline \multicolumn{7}{|l|}{$\begin{array}{l}\text { 7. "If all advertising were stopped, the consumer would } \\
\text { be better off." (Lundstrom and Lamont, 1976) }\end{array}$} \\
\hline \multicolumn{7}{|l|}{$\begin{array}{l}\text { 8. "Most manufacturers are more interested in making } \\
\text { profits than in serving consumers." (Barksdale and } \\
\text { Darden, 1972) }\end{array}$} \\
\hline \multicolumn{7}{|l|}{$\begin{array}{l}\text { 9. "Manufacturers seem to be more sensitive to consumer } \\
\text { complaints now than they were in the past." (Barksdale } \\
\text { and Darden, 1972) }\end{array}$} \\
\hline \multicolumn{7}{|l|}{$\begin{array}{l}\text { 10. "I use brand names as a sign of quality for purchasing } \\
\text { products." (Strizhakova, Coulter, Price, 2008) }\end{array}$} \\
\hline $\begin{array}{l}\text { 11. "For most product categories, the best buy is usually } \\
\text { the private label brand." (Burton et al., 1998) }\end{array}$ & & & & & & \\
\hline
\end{tabular}




\section{Interview guide (40 minutes)}

1) Warm-up (5 min)

- Aim and context of the study (only say roughly it's about marketing, not mention authenticity), methodology: own opinion is important, anonymity, recording

- Presentation of respondent: First name, age, education, profession, family, leisure activities

- Key consumption behavior factors: when buying something, according to which criteria are you choosing? Food preferences and nutrition specifics, fashion preferences

2) Marketing in general \& Branding (10 min)

- Spontaneous reaction to "marketing"

- Intro: short explanation what marketers would include in the term marketing: advertising, promotions, packaging, product development...

- Evaluation: positives and negatives (is it useful sometimes?, are there any negative points? $\rightarrow$ try to find out to what extent there are likes/dislikes: do you often care about it? Where does this come from?

How do you feel at the specific points as a consumer?)

- If negatives:

- Reasoning behind where does skepticism/likes come from

(paying attention if elaborated reasons come up: domination, cultural imperialism, value incongruence, functional dissatisfaction, perceived risk, deceptiveness, homogenization, saturation)

- At what level: capitalism, organizational, product, brands, advertising

- Consequences: where does it lead to? Behavioral change?

- Branding: Do you have any favorite brands? What are common characteristics of them? Are there brands you reject/avoid? Why?

\section{3) Authenticity (15 min)}

- Intro: explanation of brand image.

("a brand is not only a name and the relevant product, but people always have an image in mind about a brand, sometimes a whole world comes up: e.g. Marlboro - cowboys, horses, desert, but also values such as freedom, independence")

- Show brands (12 in total, no order)

\begin{tabular}{ll}
\multicolumn{1}{c}{ "authentic" brand } & \multicolumn{1}{c}{ "inauthentic" classical counterpart } \\
Sylter Salatfrische & Knorr Salatdressig \\
\hline Tannenzäpfle & Becks Gold \\
\hline Bonne Maman & Zentis \\
\hline Fritz Kola & Fanta \\
\hline Viva con Agua & Vittel \\
\hline Buko & Philadelphia \\
\hline
\end{tabular}


- Knowledge of all brands (remove the ones they don't know)

- Buying behavior towards these brands

- Perception of brand image $\rightarrow$ let people divide them into two groups according to brand image, criteria they believe most adequate (exclude category and texture)

(Take a picture of the arrangement)

Which ones are liked more, which ones less and why?

- Differentiation criteria: what distinguishes the groups in terms of brand image (Refer to the fact that there is an abstract level of distinction)

- Similarities within the groups

- Sentence completion, focus on specific brands (the ones best known):

- Compared to Fanta, Fritz Kola is....

- People who consume Viva con Agua are....

- People consuming Bacardi, Knorr and Becks Gold wear...

- The typical Becks/Fanta/Zentis user vs. the typical Tannenzäpfle/Fritz Kola/Bonne Maman user (Take the most known brand)

- Awareness: If the subject of authenticity doesn't come up. Prompt them: Are there brands that are more...than others? Ask about 1-2 other concepts beforehand.

- Tradition

- Elegance

- Authenticity

- Superiority

- Uniqueness

- Youthfulness

- Credibility

(Make a note if people had to be prompted or not)

- How would you define authenticity? What is authentic for you? What are related values?

- Authenticity construct: If some of these brands are more authentic than others: where does it come from, attributes?

\section{4) Influence on buying behavior (10-15 min)}

\subsection{Marketing-accepting people}

- Evaluation: How important is authenticity of brands for you?

- What are the benefits when buying one group or another/ brands? (also ask about inauthentic brands)

- functional

- emotional

- social

- What attributes play a role for you when choosing a brand?

\subsection{Marketing-resistant people}

- Evaluation: How important is authenticity of brands for you?

- What are the benefits when buying one group or another/ authentic brands?

- functional

- emotional

- social

- To what extent does authenticity of brands influence your buying behavior? Could authentic brands regain a part of your enthusiasm for marketing?

- What other brands would you consider authentic and why?

- Authenticity paradox: Is the term "authentic brands" a paradox for you? Why? Do you think classical brands could be authentic? 